\begin{tabular}{|c|c|c|}
\hline institute & $\begin{array}{l}\text { CARADDE: Jurnal Pengabdian Kepada Masyarakat } \\
\text { https://journal.ilininstitute.com/index.php/caradde } \\
\text { Volume } 1 \text { | Nomor } 2 \text { | Februari | } 2019 \\
\text { e-ISSN: } 2621-7910 \text { dan p-ISSN: } 2621-7961 \\
\text { DOI: https://doi.org/10.31960/caradde.v1i2.40 }\end{array}$ & $\begin{array}{l}\text { Rîi } \\
\text { CARADDE }\end{array}$ \\
\hline
\end{tabular}

\title{
Gerakan Masyarakat Hidup Sehat Anti Demam Berdarah Dengue (DBD)
}

Andi Sifiana $^{1}$, Sugiyanto ${ }^{2}$

Keywords:

Gerakan Masyarakat Hidup

Sehat Anti Demam Berdarah;

Desa Purwosari;

\section{Corespondensi Author}

Ilmu Keperawatan, STIKES Bhakti

Pertiwi Luwu Raya Palopo

Perum. Griya Sinar Cendana No.33

Maros

Email: andisilfiana2007@gmail.com

\section{History Artikel}

Received: Oktober-2018;

Reviewed: November-2018

Accepted: Desember-2018

Published: Februari-2018
Abstrak. Tujuan: Program Kemitraan Masyarakat

Gerakan Masyarakat Hidup Sehat Anti Demam Berdarah

Dengue (DBD) bertujuan untuk meningkatkan derajat kesehatan masyarakat di wilayah kerja Puskesmas Tomoni Timur. Berdasarkah hasil diskusi dengan masyarakat dan petugas kesehatan maka didapatkan permasalahan sebagai berikut 1) Tingginya angka penyakit $D B D$, 2) Minimnya pengetahuan dan sikap masyarakat tentang PHBS, 3) Tidak optimalnya kader posyandu, 4) Rendahnya kepedulian masyarakat terhadap pencegahan dan deteksi didni penyakit, 5) Tingginya angka perokok aktif, 6) Minimnya Penggunaan jamban keluarga. Metode: Pelaksanaan Program Kemitraan Masyarakat ini dilaksanakan dengan tiga pola yaitu Health Education, Healt Protection, Prevention. Sedangkan tahapan pelaksanaanya meliputi; tahapan sosialisasi, tahapan implementasi dan tahapan evaluasi. Hasil: Hasil kegiatan Program Pengabdian Masyarakat ini meliputi; pembentukan satgas Jumantik dan pemberantasan sarang nyamuk (PSN) $3 M$ Plus, penyuluhan tentang bahaya asap rokok, penyuluhan tentang PHBS, pemeriksaan kesehatan, dan pembuatan jamban percontohan. Simpulan: Pelaksanaan PKM Gerakan Masyarakat Hidup Bersih dan Sehat khususnya penanggulangan Demam Berdarah Dengue (DBD) bertujuan untuk meningkatkan derajat kesehatan masyarakat di Desa Purwosari, aparat pemerintah Desa Purwosari, Masyarakat dan juga siswa SDN 171 Purwosari sangat responsif dalam setiap program yang dilakukan dengan pendekatan kemitraan sehingga dapat berjalan sesuai dengan harapan. Kegiatan ini juga telah berjalan dengan baik tanpa ada hambatan yang berarti.

\section{PENDAHULUAN}

Tantangan pembangunan kesehatan Indonesia saat ini adalah masalah kesehatan triple burden, yaitu masih tingginya penyakit infeksi, meningkatnya penyakit tidak menular dan penyakit yang seharusnya sudah teratasi muncul kembali, selain itu factor lingkungan dan cuaca juga mempengaruhi timbulnya penyakit. Salah satunya adalah penyakit Demam Berdarah Dengue (DBD). Penyakit ini disebabkan karena gigitan nyamuk Aedes aegypti dan Aedes albopicus (Ginanjar, 2008; Anggraini, D.S., 2010). Nyamuk ini akan 
berkembang biak dengan cepat pada lingkungan yang tidak bersih (banyak genangan air dan sampah) apalagi pada musim penghujan seperti saat ini, maka akan meningkatkan kasus DBD (Sintorini, M.M., 2007; Widiyono, 2008).

Untuk menekan jumlah penderita dan kematian akibat DBD, Kementerian Kesehatan terus menggalakkan Pemberantasan Sarang Nyamuk (PSN) dan mengeluarkan surat edaran untuk menghimbau dan mendorong masyarakat, yang dimulai dari seluruh pegawai Aparatur Sipil Negara (ASN) di lingkungan Kemenkes untuk melakukan upaya pencegahan dan Pengendalian penyakit DBD. Surat Nomor PM.01.11/MENKES/591/2016 tanggal 8 November 2016 mengatur tata laksana Pemberantasan Sarang Nyamuk (PSN) 3M Plus dengan Gerakan satu rumah satu (Juru Pemantau Jentik) Jumantik.

Pada dasarnya, pencegahan penyakit DBD sangat tergantung pada perilaku individu dimasyarakat (Widiyono, 2008). Pentingnya perubahan pola hidup masyarakat ke arah yang lebih sehat, mendasari program prioritas Pembangunan Kesehatan pada periode 2015-2019 yang dilaksanakan melalui Program Indonesia Sehat dengan Pendekatan Keluarga. Program Indonesia Sehat dengan Pendekatan Keluarga dilaksanakan secara bertahap dengan target pada akhir tahun 2019, seluruh Puskesmas di Indonesia telah dapat melaksanakannya. Tahun 2018, Kemenkes memfokuskan pada sembilan provinsi prioritas, yaitu Sumatera Utara, Sumatera Selatan, Lampung, Banten, DKI Jakarta, Jawa Barat, Jawa Timur, Jawa Tengah dan Sulawesi Selatan. Berdasar pengalaman dari sembilan Provinsi prioritas tersebut, akan menggerakkan provinsi lain untuk melaksanakan di wilayahnya.

Berdasarkan hasil Focus Group Discussion (FGD) baik dengan masyarakat desa ataupun dengan petugas kesehatan di Puskesmas, didapatkan bahwa diantara wilayah Kecamatan Tomoni Timur Kabupaten Luwu Timur yang masih belum maksimal menerapkan Pola Hidup Bersih dan Sehat adalah di Desa Purwosari. Berikut identifikasi profil Desa Purwosari berdasarkan hasil FGD sebagai mitra 1 dalam Program Kemitraan Masyarakat, adalah:
Pertama, Desa Purwosari, memiliki penduduk berjumlah 1.946 jiwa yang terbagi menjadi dua dusun yaitu dusun Argosari dan dusun Argomulyo (Profil Desa Purwosari, 2016). Desa Purwosari merupakan salah satu desa yang ada di kecamatan Tomoni Timur dengan kondisi geografis dataran rendah yang masih relatif asli. Karena merupakan wilayah dengan dataran rendah memungkinkan ketika musim penghujan datang seperti saat ini akan menimbulkan banjir dan genangan air disekitar pemukimam warga yang dapat menjadi tempat perkembang biakan nyamuk.

Kedua, masyarakat Desa Purwosari sebagian besar penduduknya memiliki mata pencaharian sebagai petani yakni petani Sawah (Ladang) dan Petani Cokelat. Kecenderungan aktifitas masyarakat sebagai petani ini memungkinkan berbagai permasalahan kesehatan yang muncul dalam masyarakat, keluarga dan masing-masing individu di wilayah tersebut.

Ketiga, derajat kesehatan yang ada pada wilayah tersebut belum meningkat. Masih terdapat 46 (empat puluh enam) persen, warga Desa Purwosari tidak memiliki Jamban keluarga, karena mengandalkan sungai besar. Masyarakatnya yang mayoritas adalah petani adalah perokok aktif yang belum pernah diedukasi secara langsung dan terencana, prilaku hidup bersih dan sehat masih kurang, pemberian ASI Ekslusif yang tergantikan oleh susu formula, kurang olah raga sehingga aktifitas fisik sangat minim dan lingkungan sekitar rumah yang tidak terjaga. Sebagian dari masyarakat yang ada disana masih mempercayai dukun sebagai seseorang yang mampu memberikan pengobatan.

Keempat,beberapa informasi cakupan kesehatan, sebagai berikut; riwayat penyakit; Demam Berdarah 5 kasus, Diare, 130 kasus, Tubercolosis 10 kasus, DM 3 kasus, sedangkan HIV/AIDS 3 kasus. Cakupan penyuluhan tentang Perilaku Hidup Bersih belumpernah dilaksanakan, penyuluhan Kesehatan Reproduksi 682, Penyuluhan KB 553, dan Penyukuhan HIV/AIDS belum pernah dilakukan. Jumlah Pasangan Usia Subur 983, sedangkan cakupan pengguna dan peserta KB aktif IUD 7 pasangan, MOW 27, dan kondom 30 pasangan, Implant 90, Suntikan 504 Pil 128, total peserta KB aktif sebanyak 786. Berarti masih ada 197 orang 
belum mengikuti program Keluarga Berencana.

Kelima, prilaku hidup berseih dan sehat masih kurang dipraktikan oleh warga desa Purwosari. Sebagian besar warga menggunakan bak mandi namun jarang di kuras airnya, banyaknya sampah-sampah berupa kaleng bekas, batok kelapa, kulit cokelat dan ban bekas disekitar rumah yang dapat menampung air ketika hujan sehingga menjadi sarang nyamuk. Kondisi selokan yang tidak lancer dan banyaknya genangangenangan air dilingkungan disekitar rumah warga yang dapat menjadi sarang nyamuk. Kebiasaan warga yang membuang sampah di sekitar rumah juga berdampak terhadap kesehatan. Serta kondisi air sumur yang terkadang tidak higienis.

Mitra 2 adalah Puskesmas Tomoni Timur yang telah melakukan berbagai macam upaya dalam peningkatan derajat kesehatan masyarakat, baik secara langsung maupun tidak langsung melalui kegiatan "mobile akselerasi Kesehatan" yang telah dilaksanakan di berbagai kecamatan.

Melihat persoalan yang muncul di desa Purwosari, sangat diperlukan program yang dapat dijadikan edukasi sekaligus tindaklanjut implementasi dari surat edaran Kementrian Kesehatan Republik Indonesia Nomor PM.01.11/MENKES/591/2016 tanggal 8 November 2016 mengatur tata laksana Pemberantasan Sarang Nyamuk (PSN) 3M Plus dengan Gerakan satu rumah satu (Juru Pemantau Jentik) Jumantik dan Instruksi Presiden Republik Indonesia Nomor 1 Tahun 2017 Tentang Gerakan Masyarakat Hidup Sehat. Kegiatan PKM "Gerakan Masyarakat Hidup Sehat Anti Demam Berdarah Dengue" adalah wujud kepedulian perguruan tinggi bermitra dengan masyarakat untuk secara aktif memecahkan persoalan yang terkait dengan Pola Hidup Bersih dan Sehat. Oleh karena itu, mitra yang akan dilibatkan dalam kegiatan ini adalah Tokoh Masyarakat, Kepala Puskesmas, Kepala Desa, Kepala Dusun, ketua RT/RW dan kader-kader posyandu sebagai komponen paling utama dalam Program Gerakan Masyarakat Hidup Sehat Anti Demam Berdarah Dengue.

Berdasarkan hasil Fokus Group Discussion (FGD) dan pengamatan di lapangan, maka ditemukan permasalahan yang dihadapi oleh mitra adalah sebagai berikut: a) tingginya angka kejadian penyakit Demam Berdarah, sehingga berdampak pada kualitas hidup sehat masyarakat desa Purwosari, b) tingginya angka perokok aktif, sehingga dapat menurunkan kualitas hidup sehat masyarakat desa Purwosari baik pada aspek kesehatan maupun ekonomi, c) minimnya pengetahuan dan sikap masyarakat desa Purwosari tentang perilaku hidup Bersih dan Sehat, d) tidak optimalnya kader-kader posyandu di desa Purwosari sebagai ujung tombak program kesehatan dari Puskesmas, e) masyarakat tidak memiliki kepedulian terhadap pencegahan dan deteksi dini penyakit, f) penggunaan jamban keluarga yang masih minim. Masyarakat masih menggunakan paradigma lama dengan mengandalkan sungai besar yang membelah desa Purwosari sebagai tempat Buang Air Besar, mencuci, mandi, dan bahkan sebagai sumber air minum.

Dari beberapa permasalahan dari mitra, maka strategi atau solusi yang ditetapkan untuk menyelesaikan masalah tersebut adalah sebagai berikut: a) melakukan penyuluhan tentang pencegahan, penanganan dan pengobatan pada penyakit DBD dan kampanye Pemberantasan Sarang Nyamuk (PSN), 3M Plus dengan Gerakan satu rumah satu (Juru Pemantau Jentik) Jumantik, b) elatihan dan penyuluhan tentang prilaku hidup bersih dan sehat, c) mengoptimalisasikan kader-kader posyandu serta rekruitmen dan pembentukan Satgas Gerakan Masyarakat Hidup Sehat Anti Demam Berdarah Dengue, d) pelatihan dan pendampingan masyarakat serta deteksi dini penyakit seperti Ispa, DBD, Tipoid, jantung, kanker, dan lain sebagainya, sehingga kepedulian masyarakat terhadap pencegahan dan deteksi dini penyakit meningkat, e) menetapkan Kawasan Tanpa Rokok, yang dilanjutkan dengan penyuluhan bahaya rokok terhadap kesehatan diri sendiri dan orang di sekitarnya. Kegiatan ini akan melibatkan Tokoh masyarakat, Dinas Kesehatan, Puskesmas, sekolah, dan masyarakat, dan f) mengadakan jamban percontohan.

\section{METODE}

Dalam melaksanakan kegiatan Program Kemitraan Masyarakat ini, tim pelaksana membagi kegiatan dalam pembimbingan dan 
pendampingan. Tiga pola yang digunakan adalah; pertama, health education yang digunakan untuk memberi penerangan yang baik kepada masyarakat agar dapat bekerja sama dan mencapai apa yang diinginkan, pola hidup sehat. Konsep sehat adalah konsep seseorang dalam keadaan semputrna baik fisik, mental dan sosialnya serta bebas dari penyakit cacat dan kelemahannya. Kedua, Health Protection sebagai Perlindungan khusus dilakukan melalui tindakan tertentu misalnya imunisasi atau proteksi pada bahan industri berbahaya dan bising.. Ketiga, Prevention, yakni dengan melakukan berbagai tindakan untuk menghindari terjadinya berbagai masalah kesehatan yang mengancam pribadi dan orang disekelilingnya, misalnya dengan menjaga kebersihan lingkungan agar tidak terkena DBD.

Selain itu, model pemberdayaan masyarakat pada kelompok non-ekonomi dapat diadopsi dua model, yakni; 1) Model eko-efesiensi (eco-development). Konsep ekoefesiensi yang oleh Soemarwoto (2001) diartikan sebagai perpaduan sinergis antara komponen ekologi dan ekonomi. Ekoefesiensi bertujuan memperoleh efesiensi dari aspek ekonomi maupun ekologi yang menyangkut keberlanjutan lingkungan hidup sebagai penopang kehidupan manusia. Program Kemitraan Masyarakat ini didesain untuk meningkatkan proses kemandirian dan pemberdayaan sasaran namun tidak meninggalkan hubungan yang simbiosis dengan lingkungan hidup serta jaminan keberlanjutan pada masa mendatang; dan 2) Model Center for Environment and Society. Model Center for Environment and Society, didefinisikan sebagai suatu usaha berkelanjutan yang merupakan suatu cara memanfaatkan barang alamiah dan jasa yang tidak merusak lingkungan dan memanfaatkan pengetahuan serta keterampilan mitra yang dipilih. Model ini juga dapat diterapkan yaitu dengan memanfaatkan penggunaan secara produktif "social capital" atau modal sosial yaitu kemampuan orang untuk bekerjasama dalam memecahkan permasalahan mitra dalam pengelolaan produksi abon dan kerupuk ikan lele. Unsur social capital yang dapat dijadikan faktor pendukung pelaksanaan program kegiatan ini salah diantaranya adalah konsep Tudang Sipulung (duduk bersama menyelesaikan masalah), yang berujung pada meningkatnya sikap gotong royong.

Dari beberapa permasalahan yang muncul pada mitra, maka tim membuat rincian tahapan pelaksanaan Program Kemitraan Masyarakat sebagai berikut: (a) Tahapan I; dilakukan sosialisasi Gerakan Masyarakat Sadar Kesehatan sebagai salah satu program Pemerintah Pusat di Desa Purwosari Kecamatan Tomoni Timur yang melibatkan Kepala Puskesmas, Kepala Desa, kepala Dususn, ketua RT/RW, Tokoh masyarakat, dan kader Posyandu dan masyarakat. Sosialisasi dilaksanakan juga untuk lebih mengenal situasi lingkungan dan melakukan advokasi terhadap berbagai permasalahan pola hidup sehat di Desa Purwosari Kecamatan Tomoni Timur; (b) Tahapan II; implementasi program yang disepakati bersama yaitu; 1) penyuluhan dan Kampanye Pemberantasan Sarang Nyamuk (PSN), 3M Plus dengan Gerakan satu rumah satu (Juru Pemantau Jentik) Jumantik, 2) pelatihan, penyuluhan dan pendampingan program PHBS, 3) rekruitmen Satgas Gerakan Masyarakat Hidup Sehat Anti Demam Berdarah Dengue (DBD), 4) deteksi dini penyakit, 5) kampanye anti rokok (penyuluhan, pamflet, kawasan tanpa rokok), dan pembuatan Jamban percontohan; (c) Tahap III; adalah monitoring dan evaluasi program. Untuk menjaga keberlanjutan program, maka Tim Pengusul akan melakukan pendampingan dengan melibatkan berbagai pihak yang berwenang, Kepala Puskesmas, Kepala Desa, kepala Dususn, ketua RT/RW, Tokoh Masyarakat, dan Satgas Gerakan Masyarakat Hidup Sehat.

\section{HASIL DAN PEMBAHASAN}

a. Persiapan Pelaksanaan Program

Kegiatan Program Kemitraan Masyarakat (PKM) "Gerakan Masyarakat Hidup Sehat Anti Demam Berdarah Dengue (DBD) di Desa Purwosari" diawali dengan proses pengurusan perizinan dari Lembaga Penelitian dan Pengabdian pada Masyarakat (LP2M) STIKes Bhakti Pertiwi Luwu Raya Palopo kepada Dinas Penanaman Modal dan Pelayanan Terpadu Satu Pintu Kabupaten Luwu Timur pada tanggal 11 Mei 2018. Kemudian selanjutnya Dinas Perizinan 
memberikan rekomendasi untuk melakukan kegiatan kepada Kepala Pemerintahan Kecamatan Tomoni Timur, Puskesmas Tomoni Timur dan Kepala Pemerintahan Desa Purwosari.

\section{b. Realisasi Kegiatan}

1) Pembentukan Satuan Tugas (Satgas) Juru Pemantau Jentik (Jumantik)

Salah satu faktor belum efektifnya pencegahan DBD di Indonesia adalah masih lemahnya sistem kewaspadaan dini. Peran juru pantau jentik (jumantik) sangat penting dalam sistem kewaspadaan dini mewabahnya DBD karena berfungsi untuk memantau keberadaan dan menghambat perkembangan awal dari vektor penular DBD (Diana Andriyani Pratamawati. 2012)

Desa Purwosari merupakan salah satu desa yang terletak di Kecamatan Tomoni Timur. Desa Purwosari terdiri dari 2 Dusun, yaitu Dusun Argosari dan Dusun Argomulyo Di setiap dusun dibentuk 5 orang satgas jumantik yang terdiri dari 1 orang koordinator dan 4 orang pelaksana. Setelah didapatkan data tentang 10 warga yang bertugas sebagai satgas Jumantik, kemudian diberikan penjelasan mengenai tugas dan tanggung jawab sebagai satgas Jumantik. Tugas satgas jumantik dalam memantau wilayah meliputi; a) mengecek tempat penampungan air dan tempat yang dapat tergenang air bersih apakah ada jentik dan apakah sudah tertutup rapat. Untuk tempat air yang sulit dikuras diberi bubuk larvasida seperti abate, b) membasmi keberadaan kain/ pakaian yang tergantung didalam rumah, c) mengecek saluran air dan kolam ikan agar bebas dari jentik nyamuk, d) menyambangi rumah kosong/tidak berpenghuni untuk cek jentik.

Selain satgas jumantik sebanyak 10 orang, program yang akan dilaksanakan juga dibantu oleh pihak Puskesmas Tomoni Timur yang terdiri dari 1 orang penanggung jawab promosi kesehatan secara umum, penanggung jawab program penyakit $\mathrm{DBD}$, dan 2 orang supervisor jumantik yang akan berkoordinasi dengan masing-masing koordinator jumantik di setiap dusun.

Setiap satgas pelaksana bertanggung jawab kepada koordinator di setiap dusun. Satgas pelaksana bertugas untuk melakukan pengecekan keberadaan jentik nyamuk di setiap rumah warga secara berkala setiap bulan. Hasil yang didapatkan dilaporkan kepada koordinator. Kemudian untuk selanjutnya data dari koordinator akan dilaporkan kepada supervisor selanjutnya diteruskan ke penanggung jawab program promosi kesehatan di Puskesmas khususnya untuk penyakit demam berdarah untuk ditindaklanjuti.

Kegiatan Pemberantasan Sarang Nyamuk (PSN) dilakukan oleh satgas jumantik serta petugas kesehatan dari Puskesmas Tomoni Timur. Kegiatan PSN dijadwalkan dilaksanakan pada tanggal 27 Juli 2018 setelah dilakukan pelantikan satgas secara resmi yang dijadwalkan dilaksanakan pada tanggal 25 Juli 2018. Pihak Puskesmas dan juga Pemerintah Desa Purwosari menyambut baik mengenai rencana pembentukan satgas jumantik, hal ini terlihat dari upaya pihak Puskesmas yang langsung mengkoordinir mengenai orang-orang yang akan berperan sebagai satgas jumantik dibawah tanggung jawab pemegang program penyakit DBD yaitu Komang, S.Kep. Ns.

2) Pelantikan Satgas Jumantik dan Pelaksanaan Pemberantasan Sarang Nyamuk (PSN) 3M Plus

Setelah berkoordinasi dengan pihak Puskesmas Tomoni Timur dan Kepala Pemerintahan Desa Purwosari, pada tanggal 25 Juli 2018 dilakukan pelantikan satgas jumantik oleh Kepala Pemerintahan Desa Purwosari Kecamatan Tomoni Timur. Satgas jumantik yang dilantik berjumlah 10 orang. Setelah terbentuk, selanjutnya pada tanggal 26 s/d 27 Juli 2018 dilakukan Pemberantasan Sarang Nyamuk (PSN) di Desa Purwosari Kecamatan Tomoni Timur. Pada tanggal 26 Juli 2018 PSN difokuskan di Dusun Argosari, sementara pada tanggal 27 Juli 2018 PSN dilakukan di Dusun Argomulyo.

PSN kami lakukan bersama oleh satgas jumantik dan juga penanggung jawab Puskesmas program promosi kesehatan. PSN dilakukan dengan cara memeriksa setiap rumah yang ada di Desa Purwosari mengenai keberadaan jentik nyamuknya. Selain di bak mandi, pemeriksaan juga dilakukan di tempat-tempat yang terdapat genangan air seperti ban bekas, kaleng, tempurung kelapa. Selain pemeriksaan jentik nyamuk, dilakukan juga pemberian bubuk abate di tiap rumah dan juga memberikan pendidikan kesehatan mengenai pencegahan demam berdarah bagi 
Caradde: Jurnal Pengabdian Kepada Masyarakat

Vol 1 No 2, Februari 2019

warga yang didapatkan jentik nyamuk dirumahnya. Pendidikan kesehatan/ penyuluhan tentang DBD juga memegang peranan penting dalam meningkatkan pengetahuan masyarakat terhadap bahaya DBD. Ni Made Murtini et.al (2012) dalam penelitiannya menjelaskan bahwa tingkat pengetahuan masyarakat yang kurang baik tentang pencegahan penyakit dapat mempengaruhi kejadian DBD dan tingkat resiko penyakit DBD. Selain itu semakin masyarakat tidak serius dan tidak berhati-hati terhadap penularan penyakit DBD maka akan semakin rentan/beresiko terkena penyakit DBD.

Kunci pencegahan penyakit DBD adalah pengawasan yang ketat untuk pelaporan dini hasil pemantauan kepadatan vektor sehingga pengambilan tindakan tidak terlambat saat menerima laporan kasus dari lokasi wabah. Keberadaan jumantik memiliki peran vital dalam pemberantasan DBD karena bertugas memantau populasi nyamuk penular DBD dan jentiknya. Pemeriksaan jentik berkala dilakukan oleh jumantik yang bertugas melakukan kunjungan rumah setiap

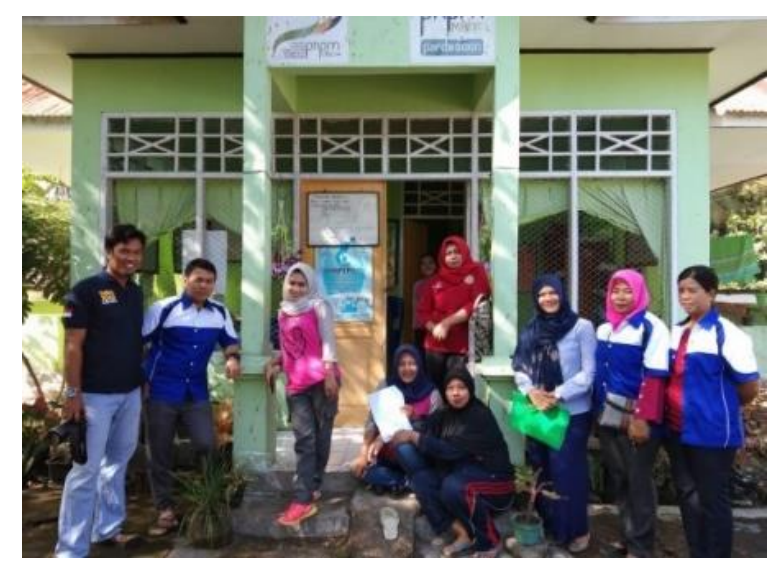

3 bulan. Hasil yang didapat jumantik dilaporkan dalam bentuk Angka Bebas Jentik (ABJ) yaitu rasio antara jumlah rumah/ bangunan yang tidak ditemukan jentik dengan jumlah rumah/ bangunan yang diperiksa dikali 100\% (Diana Andriyani Pratamawati. 2012).

Praktik PSN yang buruk adalah faktor resiko kejadian penyakit DBD. Penelitian Dharma (2012) dalam Mutia Dwi Putri et.al. (2016) menunjukkan bahwa terdapat hubungan yang bermakna antara tindakan PSN dan keberadaan jentik dengan kejadian DBD. Selain itu Triwinasis (2010) juga menunjukkan bahwa terdapat hubungan yang bermakna antara menguras dan menutup tempat penampungan air (TPA) dengan keberadaan jentik Aedes spp (dalam Mutia Dwi Putri et.al.2016). Kondisi sanitasi lingkungan juga memegang peranan penting terhadap kejadian DBD. Penelitian Anisa Anggraini (2016) mengatakan bahwa ada pengaruh yang signifikan antara kondisi sanitasi lingkungan terhadap kejadian DBD, dan ada pengaruh yang signifikan antara perilaku $3 \mathrm{M}$ plus terhadap kejadian DBD.

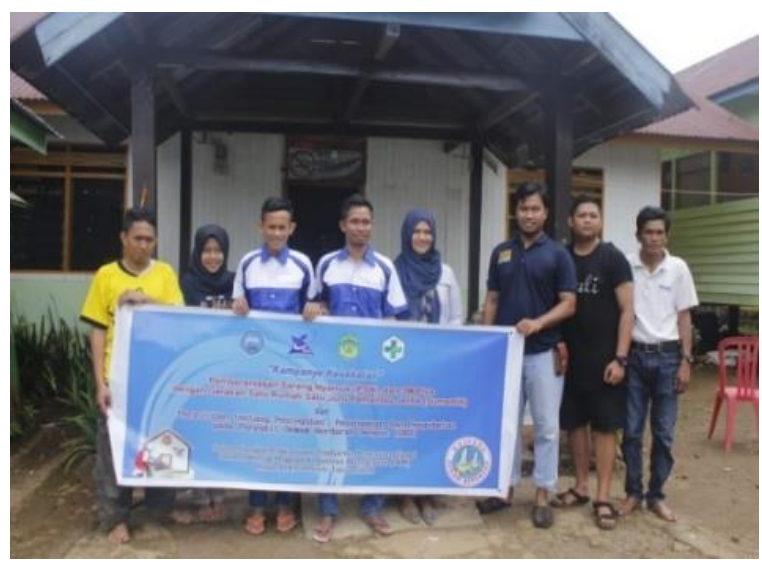

Gambar 1. Satgas Jumantik dan Penanggung Jawab Program Promkes dari Puskesmas

3) Pendidikan Kesehatan Tentang Bahaya Asap Rokok dan Pembentukan Kawasan Tanpa Asap Rokok

Kebiasaan merokok telah terbukti merupakan penyebab terhadap kurang lebih 25 jenis penyakit yang menyerang berbagai organ tubuh manusia. Penyakit-penyakit tersebut antara lain adalah kanker mulut, esophagus, faring, laring, paru, pankreas, dan kandung kemih. Juga ditemukan penyakit paru obstruktif kronis dan berbagai penyakit paru lainnya, yaitu penyakit pembuluh darah (Nururrahmah (2014).

Untuk menanggulangi masalah tersebut maka tim melaksanakan program kegiatan memberikan pendidikan kesehatan tentang bahaya asap rokok bagi anak dan pembentukan Kawasan Tanpa Asap Rokok. Kegiatan ini dilakukan di SDN 171 Purwosari. Kegiatan ini dilakukan pada tanggal 23 Agustus 2018. Peserta penyuluhan adalah siswa SDN 171 Purwosari sebanyak 65 orang yang terdiri dari siswa kelas $\mathrm{V}$ dan 
kelas VI. Topik penyuluhan adalah Bahaya Asap Rokok Bagi Anak Usia Dini. Siswa SDN 171 Purwosari sangat antusias ketika mengikuti penyuluhan tentang bahaya asap rokok bagi anak usia dini, hal ini terlihat dari banyaknya siswa yang bertanya terkait topic penyuluhan dan juga para siswa dapat menjawab pertanyaan dengan baik, yang diberikan sebagai bentuk evaluasi.

Kebiasaan mengisap rokok dapat disebabkan karena beberapa pengaruh, antara lain: 1) pengaruh orangtua, dimana salah satu temuan tentang remaja perokok adalah bahwa anak muda yang berasal dari rumah tangga yang tidak bahagia, dimana orang tua tidak begitu memperhatikan anak-anaknya dan memberikan hukuman fisik yang keras, akan lebih mudah untuk menjadi perokok dibandingkan anak-anak muda yang berasal dari lingkungan rumah tangga yang bahagia karena rokok dianggap mampu
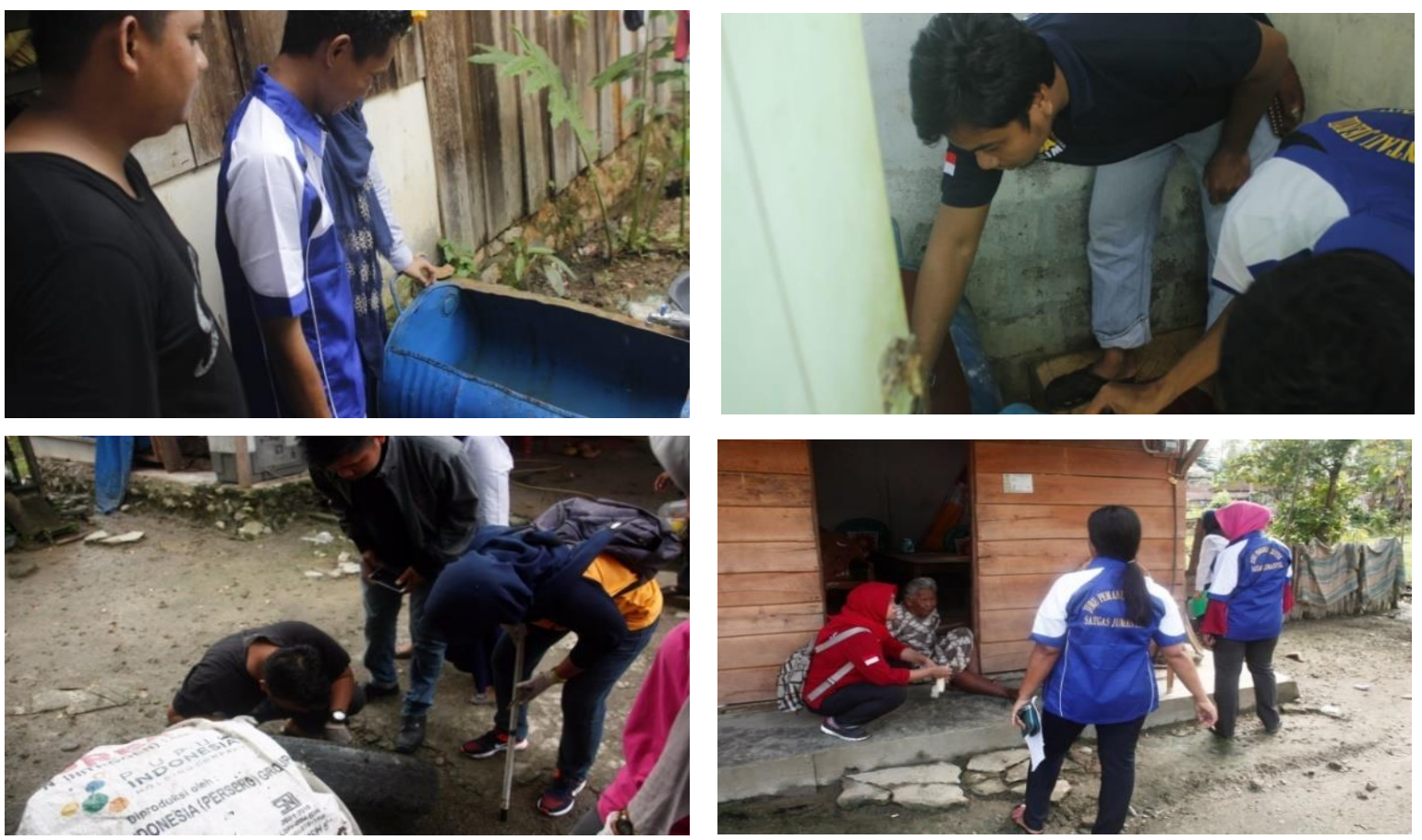

Gambar 2. Pelaksanaan Program PSN 3M Plus bersama satgas Jumantik dan Penanggung Jawab Program DBD Puskesmas Tomoni Timur menghilangkan persoalan yang mereka hadapi. Selain itu kebiasaan orang tua merokok dalam lingkungan rumah juga dapat menjadi contoh langsung bagi anak-anak untuk mengikuti pola hidup orang tuanya. 2) Pengaruh teman, dimana lingkungan pergaulan remaja akan memberi pengaruh yang sangat besar terhadap sikap dan perilaku remaja. 3) Faktor kepribadian, dimana orang mencoba untuk merokok karena alasan ingin tahu, ingin melepaskan diri dari rasa sakit, ingin membebaskan diri dari kebosanan, atau ingin dianggap sebagai pria dewasa. 4) Pengaruh Iklan, dimana iklan-iklan di media massa dan elektronik menampilkan gambaran dengan sangat jelas bahwa perokok adalah lambang kejantanan dan glamour, membuat anak dan remaja seringkali terpicu untuk mengikuti perilaku dalam iklan tersebut (Baer \& Corado dalam Nururrahmah (2014).

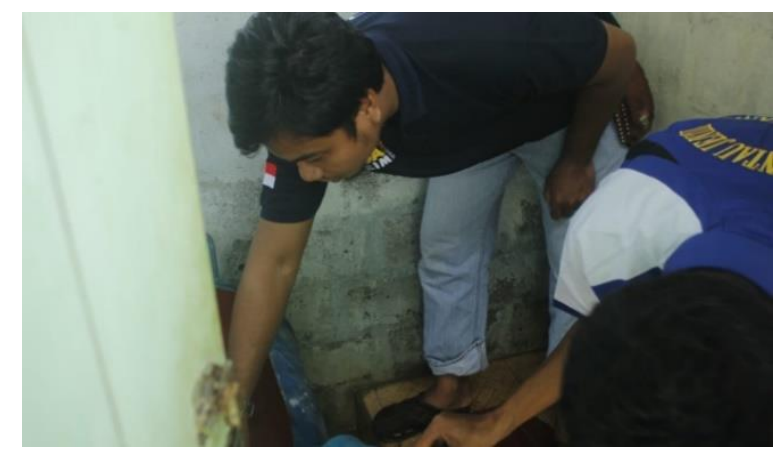
Jawab Program DBD Puskesmas Tomoni Timur 

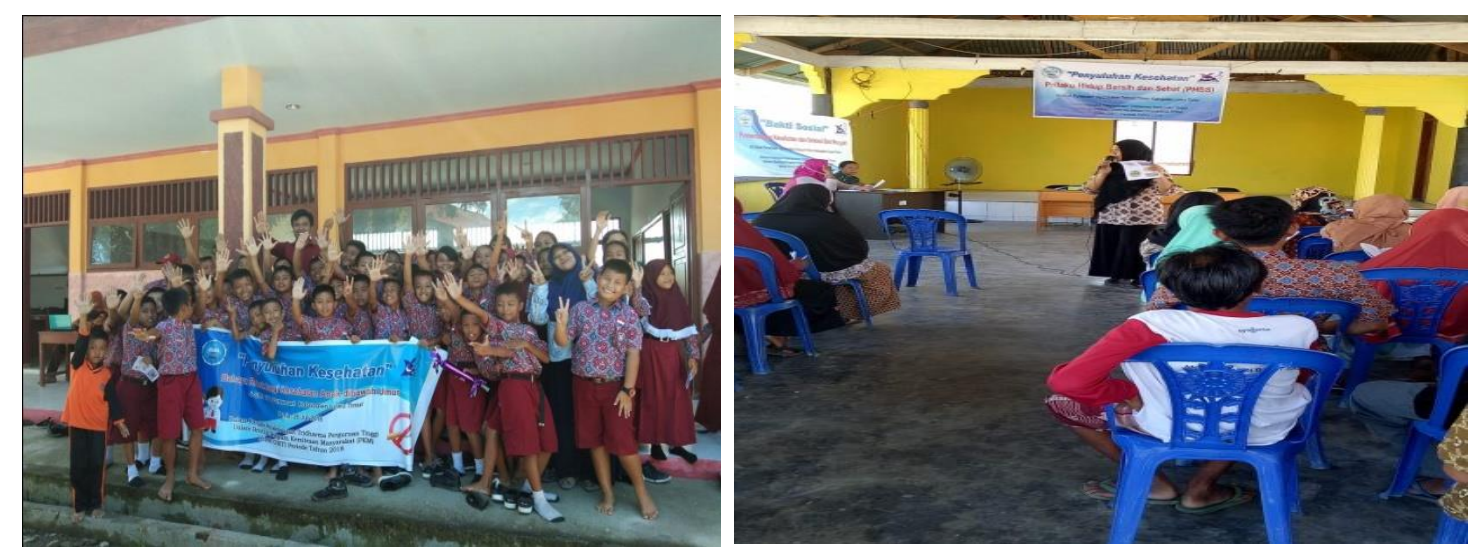

Gambar 3. Penyuluhan Kesehatan Tentang Bahaya Asap Rokok di SDN 171 Purwosari
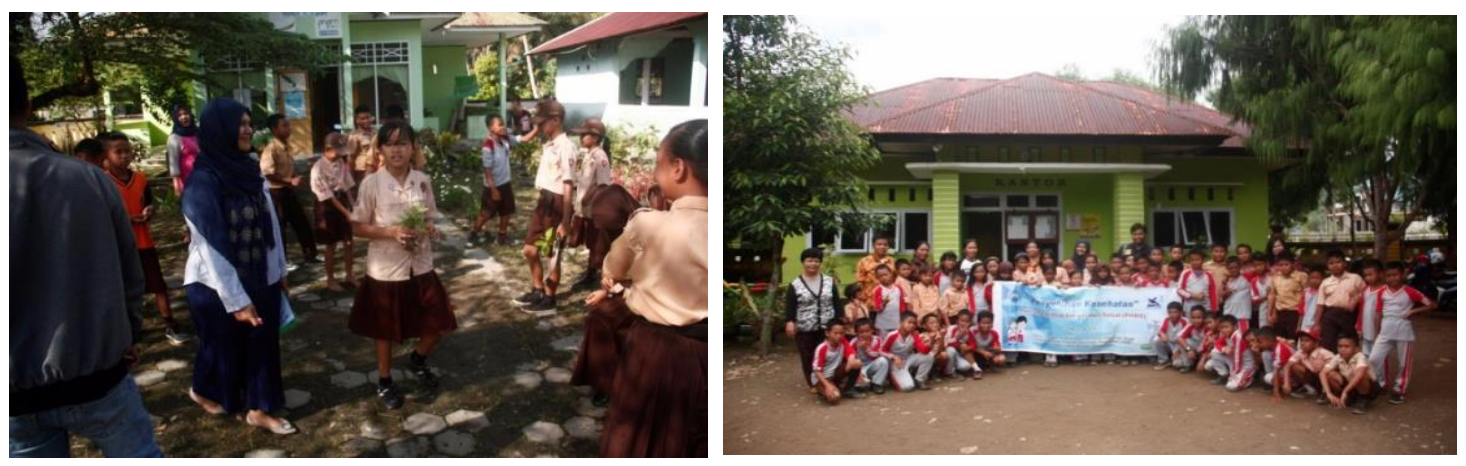

Gambar 4. Pelaksanaan Jumat Bersih dan Penyuluhan Tentang PHBS di SDN 171 Purwosari

4) Pelaksanaan Kegiatan Jumat Bersih dan Penyuluhan Tentang Pola Hidup Bersih dan Sehat (PHBS) Bagi Siswa SDN 171 Purwosari

Terdapat berbagai upaya untuk mencegah penyebaran penyakit menular sebagai akibat dari perubahan iklim. Upaya pencegahan yang paling utama dan merupakan upaya pencegahan primera dalah berbagai kegiatan manusia dan perilaku manusia yang harus dilakukan oleh keluarga/masyarakat adalah gotong royong membersihkan lingkungan sekitar dan menjaga kebersihan diri atau yang biasa di kenal sebagai Program Perilaku Hidup Bersih dan Sehat (PHBS).

Upaya PHBS jika tidak dilakukan oleh masing-masing individu atau keluarga dan anggota keluarganya akan menjadi factor risiko untuk timbulnya penyakit, baik infeksi atau penyakit tidak menular. Namun, jika upaya PHBS dilaksanakan dengan baik, maka upaya ini akan menjadi upaya yang efektif untuk mencegah penyakit menular seperti penyakit akibat dampak perubahan iklim termasuk DBD (Sintorini, M.M., 2007).
Dapat dikatakan bahwa upaya PHBS dapat menjadi determinan penyakit dan juga pencegahan penyakit (Ardini S \& Ahyani R, 2015).

Menindak lanjuti hal tersebut maka pada hari Jumat tanggal 24 Agustus 2018, tim pelaksana bekerjasama dengan pihak SDN 171 Purwosari dan juga pihak Puskesmas Tomoni Timur, dilaksanakan program Jumat bersih di sekitar lingkungan SDN 171 Purwosari. Seluruh siswa SDN 171 Purwosari dilibatkan untuk melakukan gotong royong baik didalam kelas, di halaman sekolah, maupun di lingkungan sekitar sekolah. Kegiatan dilaksanakan pukul $07.00-09.00$ WITA. Setelah selesai melaksanakan kegiatan Jumat bersih, selanjutnya untuk siswa kelas III dan IV diberikan penyuluhan tentang Pola Hidup Bersih dan Sehat (PHBS) bagi anak termasuk cara mencuci tangan yang benar. Para siswa sangat bersemangat saat mengikuti kegiatan jumat bersih dan juga mengikuti penyuluhan. Hal ini terlihat ketika para siswa diberikan pertanyaan, mereka dapat menjawab dengan baik, dan juga para siswa 
dapat mempraktekkan cara mencuci tangan yang benar.

Terdapat 10 indikator dalam PHBS, dari kesepuluh indicator tersebut, ada beberapa yang berkaitan dengan penyakit menular yang disebabkan oleh perubahan iklim, yaitu: 1) Menggunakan air bersih 2) Cuci tangan dengan sabun dan air bersih 3) Menggunakan toilet yang sehat dan 4) Menghilangkan larva di rumah sekali seminggu. Dari semua 4 faktor ini, efek yang paling berperan sebagai determinan penyakit menular adalah lingkungan dan perilaku. (Ardini S \& Ahyani R, 2015)

5) Penyuluhan dan Pemeriksaan Kesehatan Bagi Warga Desa Purwosari serta Penyerahan Alat Kesehatan kepada Puskesmas Tomoni Timur

Penyuluhan kesehatan tentang

Bahaya Asap Rokok dan Perilaku Hidup Bersih dan Sehat kepada warga Desa Purwosari dilakukan untuk meningkatkan derajat kesehatan masyarakat purwosari. Setelah dilakukan penyuluhan, dilanjutkan dengan pemeriksaan kesehatan gratis untuk warga Desa Purwosari. Pemeriksaan kesehatan yang dilakukan yaitu meliputi pemeriksaan tekanan darah, pemeriksaan kadar gula darah, pemeriksaan kadar kolesterol darah, pemeriksaan kadar asam urat dalam darah. Penyuluhan kesehatan dan Pemeriksaan kesehatan ini didukung dari pihak Pemerintahan Desa Purwosari, Puskesmas Tomoni Timur dan juga dari Poskesdes Purwosari. Kepala Pemerintahan Desa Purwosari menyiapkan tempat untuk dilaksanakannya penyuluhan dan pemeriksaan kesehatan gratis, yaitu di Balai Desa Purwosari. Penanggung jawab program promosi kesehatan dan juga bidan Poskesdes Purwosari turut mendampingi selama pelaksanaan kegiatan ini. Warga Desa Purwosari juga memberikan tanggapan yang baik dalam pelaksanaan kegiatan ini. Hal ini dapat dilihat selama pelaksanaan penyuluhan warga secara aktif bertanya dan menjawab pertanyaan yang kami berikan. Selain itu, warga juga tampak bersemangat memeriksakan kesehatannya. Hal ini dapat dilihat dari jumlah warga yang datang berjumlah sebanyak 62 orang.

6) Pembuatan Jamban Percontohan dan Gotong Royong Bersama Warga Desa Purwosari

Perilaku menggunakan jamban merupakan cara yang paling efektif, sederhana dan murah untuk mencegah penyakit-penyakit seperti diare, tifus, kolera, disentri. Namun pelaksanaannya masih sangat minim, seperti yang terlihat di desa Purwosari dimana masyarakat sangan minim menggunakan jamban. Kurangnya kesadaran masyarakat dalam menggunakan jamban di pengaruhi oleh beberapa factor diantaranya kondisi lingkungan, sarana dan kebiasaan. Faktor-faktor yang berpengaruh secara bersama-sama terhadap perilaku seseorang adalah dukungan tokoh agama, ketersediaan sarana jamban di rumah, dukungan tokoh masyarakat, dukungan petugas kesehatan (Andrias H \& Laksmono W. (2014).

Pada tanggal 25 Oktober 2018 dilaksanakan kegiatan gotong royong bersama warga Desa Purwosari serta pembangunan jamban percontohan. Kegiatan ini didukung dari pihak pemerintahan Desa Purwosari. Kegiatan gotong royong dilaksanakan diwilayah sekitar kantor Desa Purwosari dan sekitarnya. Selain melaksanakan kegiatan gotong royong untuk membersihkan lingkungan Desa Purwosari, dilaksanakan juga pembangunan jamban percontohan. Jamban percontohan yang dibangun terletak di Dusun Argomulyo di dekat Kantor Desa Purwosari. Kegiatan ini mendapatkan dukungan penuh dari pihak pemerintahan desa Purwosari dan juga dari warga. Hal ini dapat terlihat dari banyaknya warga khususnya bapak-bapak yang bergotong royong bersama membersihkan lingkungan. Selain itu, warga juga bekerja sama membangun jamban percontohan. Dan dengan bantuan tersebut jamban percontohan dapat diselesaikan dengan baik. Dengan adanya jamban percontohan diharapkan warga akan merubah pola buang air besar yang masih ada di sungai. 
Caradde: Jurnal Pengabdian Kepada Masyarakat

Vol 1 No 2, Februari 2019
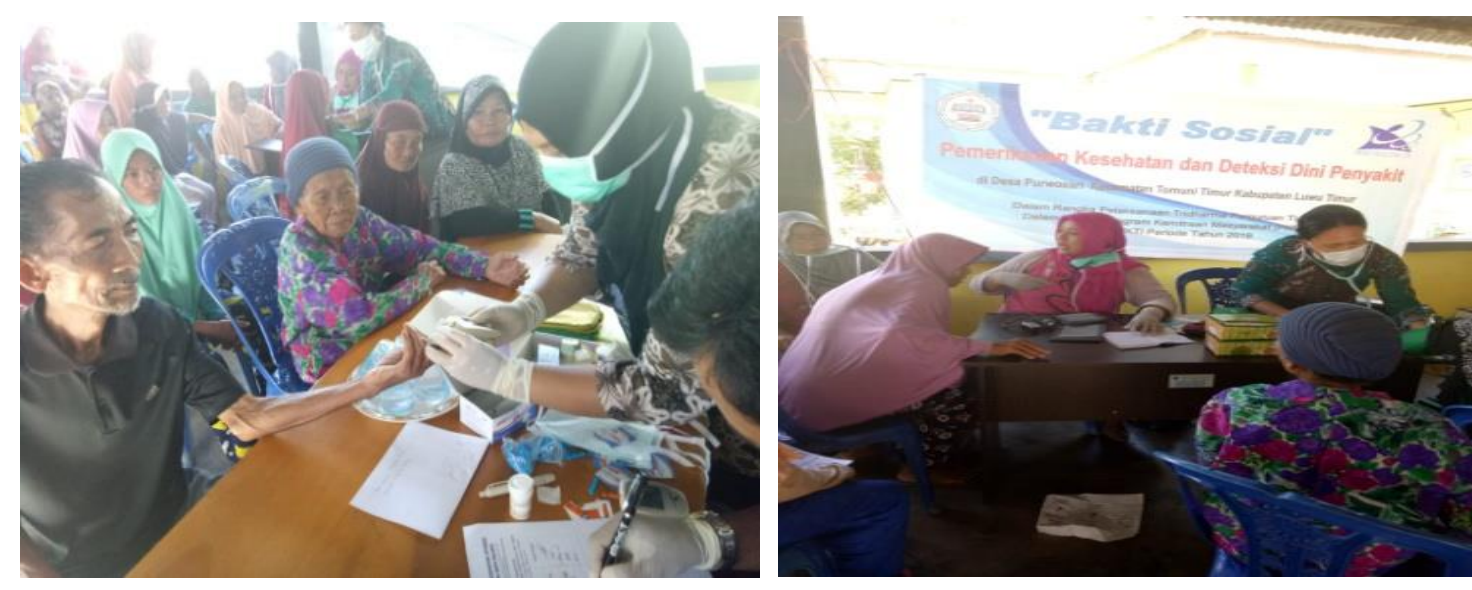

Gambar 5. Pemeriksaan Kesehatan Gratis untuk warga Desa Purwosari


Gambar 6. Penyuluhan Kesehatan Tentang PHBS dan Bahaya Merokok
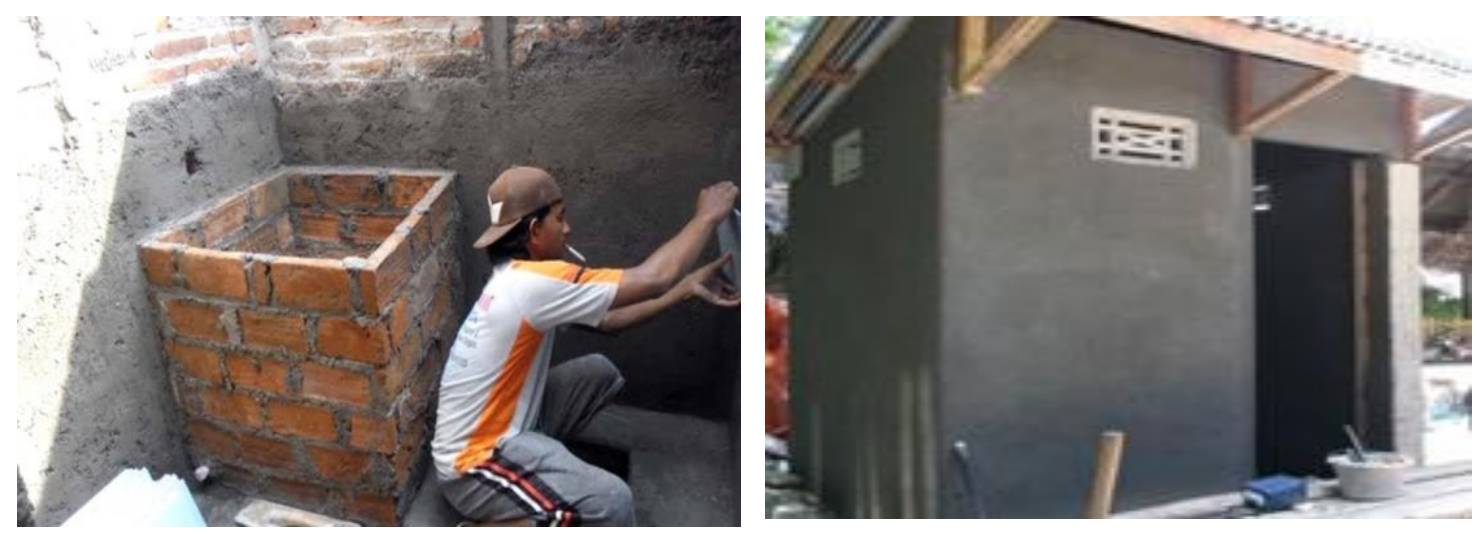

Gambar 7. Pembuatan Jamban Percontohan di Desa Purwosari

\section{SIMPULAN DAN SARAN}

Pelaksanaan PKM bertujuan untuk meningkatkan derajat kesehatan masyarakat di Desa Purwosari Kecamatan Tomoni Timur Kabupaten Luwu Timur. Pihak Puskesmas, aparat pemerintah Desa Purwosari,
Masyarakat dan juga siswa SDN 171 Purwosari sangat responsif dalam setiap program yang dilakukan dengan pendekatan kemitraan. Hanya saja, ketika akan dibentuk satgas jumantik, agak sulit untuk menemui para warga calon satgas jumantik untuk diberikan arahan mengenai tanggung jawab 
Sifiana, Sugiyanto. Gerakan Masyarakat Hidup

seorang satgas jumantik, karena kesibukan warga yang merupakan seorang petani, sehingga para satgas jumantik dikunjungi di masing-masing rumahnya untuk diberikan arahan mengenai tugas dan tanggung jawab seorang satgas jumantik. Karena kesibukan tersebut diharapkan pendampingan dan tindak lanjut dari pihak Puskesmas Tomoni Timur dan pemerintah Desa Purwosari untuk selalu mendukung kegiatan tersebut.

\section{DAFTAR RUJUKAN}

Andrias H \& Laksmono W. (2014). Perilaku Kepala Keluarga dalam Menggunakan Jamban di Desa Tawiri Kecamatan Teluk Ambon Kota Ambon. Jurnal Promosi Kesehatan Indonesia Vol. 9 / No. 2 / Agustus 2014. Universitas Dipoinegoro Semarang

Anisa Anggraini. (2016). Pengaruh Kondisi Sanitasi Lingkungan dan Perilaku 3M Plus Terhadap Kejadian Demam Berdarah Dengue di Kecamatan Purwoharjo Kabupaten Banyuwangi. Jurnal Pendidikan Geografi. Volume 03 Nomor 03 Tahun 2016, 321 - 328 Universitas Negeri Surabaya

Ardini S \& Ahyani R (2015) Perilaku Hidup Bersih dan Sehat Sebagai Determinan Kesehatan yang Penting pada Tatanan Rumah Tangga di Kota Bandung. Jurnal JSK, Volume 1 Nomor. 1 Tahun 2015 Departemen Ilmu Kesehatan Masyarakat Fakultas Kedokteran Unpad

Badan Perencanaan Pembangunan Kabupaten Luwu Timur. (2016). Renstra Kabupaten Luwu Timur. Malili

Diana Andriyani Pratamawati (2012). Peran Juru Pantau Jentik dalam Sistem Kewaspadaan Dini Demam Berdarah Dengue di Indonesia. Jurnal Kesehatan Masyarakat Nasional Vol. 6, No. 6, Juni 2012 https://media.neliti.com/media/pu blications/39719-ID

Direktorat Riset dan Pengabdian kepada Masyarakat, (2017). Panduan
Pelaksanaan Penelitian dan Pengabdian kepada Masyarakat di Perguruan Tinggi Edisi XI Tahun 2017. Jakarta

Ervin, Naomi, E` (2012). Anvanced Community Health Nursing Practic, Population Focused Care. Prentice Hall, New Jersey.

Kementrian Kesehatan Republik Indonesia (2016). Kemenkes Keluarkan Surat Edaran Pemberantasan Sarang Nyamuk Dengan $3 m$ Plus Dan Gerakan 1 Rumah 1 Jumantik. Jakarta. http://www.depkes.go.id

Kementrian Kesehatan Republik Indonesia (2017). Wilayah KLB DBD Ada di 11 Provinsi, Jakarta. http://www.depkes.go.id

Kementrian Kesehatan Republik Indonesia (2017) Instruksi PresidenRepublik Indonesia Nomor 1 Tahun 2017 Tentang Gerakan Masyarakat Hidup Sehat. Jakarta. http://www.kesmas.kemkes.go.id

Mutia Dwi Putri et.al. (2016). Hubungan Tindakan Pemberantasan Sarang Nyamuk (PSN) dengan Keberadaan Jentik Vektor Chikungunya di Kampung Taratak Paneh Kota Padang. http://jurnal.fk.unand.ac.id

Ni Made Murtini et.al (2012) Pengaruh Pengetahuan dan sikap masyarakat tentang DBD terhadap aktivitas pemberantasan sarang nyamuk di desa Dalung kecamatan Kuta Utara. Jurnal Kesehatan Lingkungan Vo.4, No.2. Poltekes Denpasar

Nururrahmah (2014) Pengaruh Rokok terhadap Kesehatan dan Pembentukan Karakter Manusia. Prosiding seminar Nasional, Vol.01, Nomor.1 Universitas Cokroaminoto Palopo.

Sintorini, M.M., (2007) Pengaruh Iklim Terhadap Kasus Demam Berdarah Dengue, Jurnal Kesehatan Masyarakat Nasional 
Caradde: Jurnal Pengabdian Kepada Masyarakat Vol 1 No 2, Februari 2019

\author{
Soemarwoto, (2011) Atur Diri Sendiri, \\ Paradigma Baru Pengelolaan \\ Lingkungan Hidup. Gadjah Mada \\ University Press, Yogyakarta
}

Widiyono, (2008) Penyakit Tropis Epidemiologi,

Penularan, Pencegahan, dan

Pemberantasannya. Jakarta, Erlangga 